\title{
Economic Reforms and Human Development Indicators in India*
}

\author{
Raghbendra JHA† \\ Australian National University
}

This paper sketches the contours of progress in India across a broad range of human development indicators, especially those related to the Millennium Development Goals. This paper also considers the slackening of the drop in poverty reduction since the 1990s (as compared to the 1980s) and the theme of increasing personal and regional inequality in India in the post-reforms period. It also considers the even more persistent incidence of hunger in India and concludes by assessing the potential role of public policy in addressing the twin problems of slowdown in poverty alleviation and reduction of hunger.

Key words India, human development indicators, hunger, poverty

JEL codes D13, I3, O18, O53

... markets can only serve those who are part of the market system. A vast number of people in our country live on the edges of a subsistence economy. We need credible programs of direct intervention focusing on the needs of these people. We have the responsibility to provide them with quality social services, such as education, health, safe drinking water and roads....

Manmohan Singh

Delivering the 1992-1993 Government of India Budget Speech

\section{Introduction}

Even when there was widespread consensus in policy and academic circles that economic growth was essential for poverty reduction, Indian policy makers held a more nuanced view. This is illustrated by the above quote from Manmohan Singh then Finance Minister and now Prime Minister of India, were acutely aware of the limitations of market-based economic growth processes in addressing issue of mass poverty and deprivation. This paper essays the response, in the main, of two key indicators of living standards - poverty and hunger - to the sustained increase in economic growth with increasing emphasis on its inclusiveness adopted since the beginnings of the current phase of the economic

${ }^{*}$ I am grateful to Hal Hill, Takashi Kurosaki, and the editors of Asian Economic Policy Review for helpful written comments on an earlier draft. Helpful discussions with participants in a conference organized by the Japan Center for Economic Research in Tokyo in April 2008 are also acknowledged. The usual disclaimer applies.

†Correspondence: Raghbendra Jha, Australia South Asia Research Centre, The Arndt-Corden Division of Economics, Research School of Pacific \& Asian Studies, Australian National University, Canberra, ACT 0200, Australia. Email: r.jha@anu.edu.au 
reforms program in July 1991. ${ }^{1}$ Much of this deprivation is entrenched in the rural sector where, per the 2001 census, $72.18 \%$ of India's population of 1.028 billion lived. ${ }^{2}$ However, in 2006-2007, agriculture accounted for only $18.5 \%$ of India's gross domestic product (GDP). This gross mismatch between agriculture's share in GDP and the rural sector's share of the population underscores one of the critical reasons for the high incidence of poverty in the rural sector $(28.30 \%$ in $2004-2005){ }^{3}$

The value added of this paper is in analyzing the spatial variation of poverty and the tenuous link between poverty alleviation and reduction of hunger in India. This paper is organized as follows. Section 2 sketches the broad contours of progress in India across a broad range of human development indicators, especially those related to the Millennium Development Goals (MDG). Section 3 considers a key concern of this paper: the slackening of the drop in poverty reduction since the 1990s (as compared to the 1980s) and increasing personal and regional inequality in India in the post-reform period. Section 4 considers the even more persistent incidence of hunger in India. Section 5 concludes by assessing the potential role of public policy in addressing the twin problems of slowdown in poverty alleviation and the reduction of hunger.

\section{Trends in Human Development Indicators in India}

The 2007-2008 Human Development Report ranks India 128th (out of 177 countries) on its Human Development Index (HDI) for 2005. Panel A of Table 1 indicates that there has been a steady, if unspectacular, progress in India's human development indicators with no significant acceleration in the post-reforms period. Panel B disaggregates India's HDI performance into its components and compares them with those for (i) developing countries, (ii) East Asia and the Pacific, and (iii) South Asia. Developing countries and East Asia and the Pacific outperform India in respect of each of these components. However, India is the best performer in South Asia in respect of each of these components except for life expectancy, where India's performance is comparable to South Asia's. Poverty, in terms of the internationally accepted $\$ 1$ per capita benchmark, remains high (Panel C). Access to basic services such as water and sanitation has improved (Panel D), but undernourishment, particularly among children, is high. Health and education MDGs have recorded impressive growth (Panels $\mathrm{E}$ and $\mathrm{F}$ ).

Inequality in the population in respect of some of the MDGs is indicated in Table 2. The Gini index is high (Panel A) and growing, and there is considerable inequality in access to maternal and child health. Gender inequality is quite pronounced in the areas of literacy and earned income. Aggregate measures of inequality conceal even more variation at the regional level (Deolalikar, 2008).

\section{Assessment of India's Poverty in the Post-Reform Period}

India's economic growth has accelerated and become more stable in recent times. Mean growth rates of real gross national product (GNP) for successive decades have grown steadily and the standard deviation of year-to-year growth within each period has come 
Table 1 India: indicators of human development - trends and structure

Panel A: Trends in India's human development index (HDI)

\begin{tabular}{llllllll}
\hline & 1975 & 1980 & 1985 & 1990 & 1995 & 2000 & 2005 \\
\hline HDI value & 0.419 & 0.450 & 0.487 & 0.521 & 0.551 & 0.578 & 0.619 \\
\hline
\end{tabular}

Panel B: Human development indicators in 2005 (unless otherwise specified)

\begin{tabular}{|c|c|c|c|c|c|c|c|c|}
\hline Country/country group & $\begin{array}{l}\text { HDI } \\
\text { value } \\
(2005)\end{array}$ & $\begin{array}{l}\text { Life expectancy } \\
\text { at birth (years) } \\
2005\end{array}$ & $\begin{array}{l}\text { Adult literacy rate } \\
\text { (\% aged } 15 \text { and } \\
\text { above) } 1995-2005\end{array}$ & $\begin{array}{l}\text { Combined gross enrollment } \\
\text { ratio for primary, secondary, } \\
\text { and tertiary education (\%) } 2005\end{array}$ & $\begin{array}{l}\text { GDP per } \\
\text { capita (PPP \$) } \\
2005\end{array}$ & $\begin{array}{l}\text { Life } \\
\text { expectancy } \\
\text { index }\end{array}$ & $\begin{array}{l}\text { Education } \\
\text { index }\end{array}$ & $\begin{array}{l}\text { GDP } \\
\text { index }\end{array}$ \\
\hline ndia & 0.619 & 63.7 & 61.0 & 63.8 & 3452 & 0.645 & 0.620 & 0.591 \\
\hline Developing countries & 0.691 & 66.1 & 76.7 & 64.1 & 5282 & 0.685 & 0.725 & 0.662 \\
\hline ast Asia and the Pacific & 0.771 & 71.7 & 90.7 & 69.4 & 6604 & 0.779 & 0.836 & 0.699 \\
\hline outh Asia & 0.611 & 63.8 & 59.5 & 60.3 & 3416 & 0.646 & 0.598 & 0.589 \\
\hline
\end{tabular}


Table 1 Continued

Panel C: India human and income poverty in 2005 (unless otherwise specified)

\begin{tabular}{|c|c|c|c|c|c|c|c|c|c|}
\hline \multicolumn{2}{|c|}{$\begin{array}{l}\text { Human poverty } \\
\text { index (HPI-1) }\end{array}$} & \multirow[b]{2}{*}{$\begin{array}{l}\text { Probability at birth } \\
\text { of not surviving to } \\
\text { age } 40 \text { (\% of } \\
\text { cohort) } 2000-2005\end{array}$} & \multirow[b]{2}{*}{$\begin{array}{l}\text { Adult illiteracy } \\
\text { rate (\% aged } \\
15 \text { and older) } \\
1995-2005\end{array}$} & \multirow[b]{2}{*}{$\begin{array}{l}\text { Population } \\
\text { not using an } \\
\text { improved water } \\
\text { source (\%) } 2004\end{array}$} & \multirow[b]{2}{*}{$\begin{array}{l}\text { MDG: Children } \\
\text { underweight for } \\
\text { age (\% under 5) } \\
1996-2005\end{array}$} & \multicolumn{3}{|c|}{$\begin{array}{l}\text { MDG: Population below income } \\
\text { poverty line (\%) }\end{array}$} & \multirow[b]{2}{*}{$\begin{array}{l}\text { HPI-1 rank } \\
\text { minus income } \\
\text { poverty rank }\end{array}$} \\
\hline Rank & $\begin{array}{l}\text { Value } \\
(\%)\end{array}$ & & & & & $\begin{array}{l}\$ 1 \text { a day } \\
(1990-2005)\end{array}$ & $\begin{array}{l}\$ 2 \text { a day } \\
(1990-2005)\end{array}$ & $\begin{array}{l}\text { National income } \\
\text { poverty line } \\
\text { 1990-2004 }\end{array}$ & \\
\hline 62 & 31.3 & 16.8 & 39.0 & 14 & 47 & 34.3 & 80.4 & 28.6 & -13 \\
\hline
\end{tabular}

Panel D: India water, sanitation, and nutritional status

\begin{tabular}{|c|c|c|c|c|c|c|c|c|}
\hline \multicolumn{2}{|c|}{$\begin{array}{l}\text { MDG: Population } \\
\text { using improved } \\
\text { sanitation (\%) }\end{array}$} & \multicolumn{2}{|c|}{$\begin{array}{l}\text { MDG: Population } \\
\text { using an improved } \\
\text { water source }(\%)\end{array}$} & \multicolumn{2}{|c|}{$\begin{array}{l}\text { MDG: Population } \\
\text { undernourished } \\
\text { (\% of total population) }\end{array}$} & \multirow{2}{*}{$\begin{array}{l}\text { MDG: Children } \\
\text { underweight for age } \\
\text { (\% of children under 5) } \\
1996-2005\end{array}$} & \multirow{2}{*}{$\begin{array}{l}\text { Children underheight } \\
\text { for age (\% of children } \\
\text { under 5) } \\
1996-2005\end{array}$} & \multirow{2}{*}{$\begin{array}{l}\text { Infants } \\
\text { with low } \\
\text { birthweight (\% } \\
1998-2005\end{array}$} \\
\hline 1990 & 2004 & 1990 & 2004 & 1990-1992 & 2002-2004 & & & \\
\hline 14 & 33 & 70 & 86 & 25 & 20 & 47 & 51 & 30 \\
\hline
\end{tabular}


Table 1 Continued

\begin{tabular}{|c|c|c|c|c|c|c|c|c|c|}
\hline \multicolumn{10}{|c|}{ Panel E: India survival: progress and setbacks } \\
\hline \multicolumn{2}{|c|}{$\begin{array}{l}\text { Life expectancy } \\
\text { at birth (years) }\end{array}$} & \multicolumn{2}{|c|}{$\begin{array}{l}\text { MDG: Infant } \\
\text { mortality rate } \\
\text { (per } 1000 \text { live births) }\end{array}$} & \multicolumn{2}{|c|}{$\begin{array}{l}\text { MDG: Under } 5 \\
\text { mortality rate } \\
\text { (per } 1000 \text { live births) }\end{array}$} & \multicolumn{2}{|c|}{$\begin{array}{l}\text { Probability at birth of surviving } \\
\text { to age } 65 \text { ( } \% \text { of cohort) }\end{array}$} & \multicolumn{2}{|c|}{$\begin{array}{l}\text { MDG Maternal mortality ratio } \\
\text { (per } 100000 \text { live births) }\end{array}$} \\
\hline 1970-1975 & $2000-2005$ & 1970 & 2005 & 1970 & 2005 & Female 2000-2005 & Male 2000-2005 & Reported 1990-2005 & Adjusted 2005 \\
\hline 50.7 & 62.9 & 127 & 56 & 202 & 74 & 66.1 & 57.4 & 540 & 450 \\
\hline
\end{tabular}

Panel F: India literacy and enrollment

\begin{tabular}{|c|c|c|c|c|c|c|c|c|}
\hline \multicolumn{2}{|c|}{$\begin{array}{l}\text { Adult literacy } \\
\text { rate (\% aged } \\
15 \text { and over) }\end{array}$} & \multicolumn{2}{|c|}{$\begin{array}{l}\text { MDG: Youth } \\
\text { literacy rate } \\
(\% \text { aged } 15-24)\end{array}$} & \multicolumn{2}{|c|}{$\begin{array}{l}\text { MDG: Net } \\
\text { primary enrollment } \\
\text { rate }(\%)\end{array}$} & \multicolumn{2}{|c|}{$\begin{array}{l}\text { MDG: Children } \\
\text { reaching grade } 5 \\
\text { (\% of grade } 1 \text { students) }\end{array}$} & \multirow{2}{*}{$\begin{array}{l}\text { Tertiary students in science, engineering, } \\
\text { manufacturing, and construction } \\
\text { (\% of tertiary students) } \\
1999-2005\end{array}$} \\
\hline 1985-1994 & 1995-2005 & 1985-1994 & 1995-2005 & 1991 & 2005 & 1991 & 2004 & \\
\hline 48.2 & 61.0 & 61.9 & 76.4 & & 89 & & 73 & 22 \\
\hline
\end{tabular}

Source: UNDP: Human Development Report 2007-2008. 
Table 2 India: indicators of inequality at the aggregate level

Panel A: Inequality in expenditure survey, 2004-2005

MDG: Share of income or expenditure (\%)

\begin{tabular}{llllllll}
\hline Poorest 10\% & Poorest 20\% & Richest 20\% & Richest 10\% & Richest 10\% to poorest 10\% & Richest 20\% to poorest 20\% & Gini index \\
\hline 3.6 & 8.1 & 45.3 & 31.1 & 8.6 & 3.6 & 36.8 \\
\hline
\end{tabular}

Panel B: Inequalities in maternal and child health, 1998-1999

\begin{tabular}{|c|c|c|c|c|c|c|c|c|c|}
\hline \multicolumn{2}{|c|}{$\begin{array}{l}\text { Births attended by skilled } \\
\text { health personnel (\%) }\end{array}$} & \multicolumn{2}{|c|}{$\begin{array}{l}\text { One-year-olds } \\
\text { fully immunized }\end{array}$} & \multicolumn{2}{|c|}{$\begin{array}{l}\text { Children underheight } \\
\text { for age ( } \% \text { under } 5)\end{array}$} & \multicolumn{2}{|c|}{$\begin{array}{l}\text { Infant mortality rate } \\
\text { (per } 1000 \text { live births) }\end{array}$} & \multicolumn{2}{|c|}{$\begin{array}{l}\text { Under } 5 \text { mortality rate } \\
\text { (per } 1000 \text { live births) }\end{array}$} \\
\hline Poorest 20\% & Richest 20\% & Poorest $20 \%$ & Richest 20\% & Poorest $20 \%$ & Richest 20\% & Poorest 20\% & Richest 20\% & Poorest 20\% & Richest 20\% \\
\hline 16 & 84 & 21 & 64 & 58 & 27 & 97 & 38 & 141 & 46 \\
\hline
\end{tabular}

Panel C: Gender inequality

\begin{tabular}{|c|c|c|c|c|c|c|c|c|c|}
\hline \multirow{2}{*}{$\begin{array}{l}\text { Gender-related } \\
\text { development } \\
\text { (GDI) rank } \\
\text { (value) }\end{array}$} & \multicolumn{2}{|c|}{$\begin{array}{l}\text { Life expectancy } \\
\text { at birth years } \\
(2005)\end{array}$} & \multicolumn{2}{|c|}{$\begin{array}{l}\text { Adult literacy rates } \\
\text { (\% aged } 15 \text { and older) } \\
\text { 1995-2005 }\end{array}$} & \multicolumn{2}{|c|}{$\begin{array}{l}\text { Combined gross enrollment ratio } \\
\text { for primary, secondary, and } \\
\text { tertiary education (\%) } 2005\end{array}$} & \multicolumn{2}{|c|}{$\begin{array}{l}\text { Estimated earned } \\
\text { income (PPP \$) } \\
2005\end{array}$} & \multirow{2}{*}{$\begin{array}{l}\text { HDI rank } \\
\text { minus GDI } \\
\text { rank }\end{array}$} \\
\hline & Female & Male & Female & Male & Female & Male & Female & Male & \\
\hline $113(0.600)$ & 65.3 & 62.3 & 47.8 & 73.4 & 60 & 68 & 1620 & 5194 & 0 \\
\hline
\end{tabular}

Source: UNDP: Human Development Report 2007-2008. 


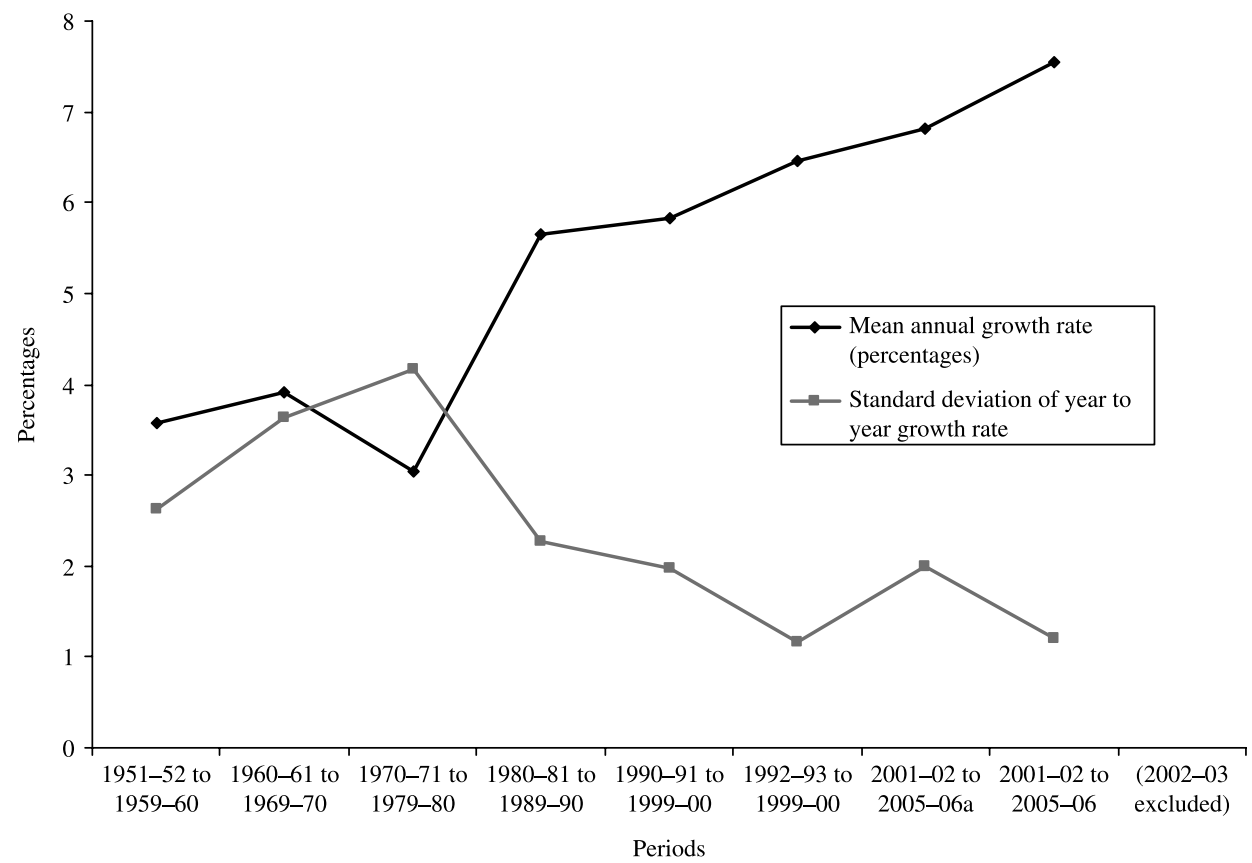

Figure 1 Real GNP: Mean annual growth and standard deviation.

Source: Author's calculations based on data from the Reserve Bank of India Handbook of Statistics on the Indian Economy.

down sharply (Figure 1). ${ }^{4}$ Real GDP growth rates have been near or in excess of $9 \%$ since 2003-2004. Real per capita GDP growth has accelerated from 1.2\% during 1972-1982 to $3.0 \%$ during 1982-1992 and 3.9\% during 1992-2002 (Kelkar, 2004). Since 2003-2004, real per capita GDP has grown in excess of $7 \%$ per annum.

I now briefly discuss the post-reform experience with poverty reduction. The poverty measures used are all drawn from the Foster-Greer-Thorbecke (FGT) class of functions described by Foster et al. (1984), written as:

$$
Y_{\alpha}=\sum_{y_{i}<z}\left[\left(z-y_{i}\right) / z\right]^{\alpha} / n
$$

where $Y$ is the measure of poverty, $y_{i}$ is the consumption of the $i$ th household or the $i$ th class of household, $z$ is the poverty line, $n$ is the population size, and $\alpha$ is a nonnegative parameter. The headcount ratio, $H C$, given by the percentage of the population who are poor is obtained when $\alpha=0$. This measure fails to capture the extent to which individual income (or expenditure) falls below the poverty line. Hence, we use the poverty gap index (PG) given by the aggregate income shortfall of the poor as a proportion of the poverty line and normalized by the population size, and obtained by setting $\alpha=1$ in (1). PG captures the acuteness of poverty since it measures the total shortfall of the poor from the poverty line (i.e. it measures the total amount of income necessary to remove that poverty). This has the drawback that it does not respond to the inequality among the poor. An FGT 
measure responding to the inequality among the poor can be obtained by setting $\alpha=2$ in (1). We call this SPG. Since all three measures capture different aspects, it is important to use the three measures jointly. In India, poverty, inequality, and consumption patterns are assessed on the basis of consumption data collected at the household level by the Central Statistical Organization through the National Sample Survey (NSS).

It would be expected that the acceleration in real GDP growth post-reform would lead to sharp falls in poverty in India. However, poverty computations do not justify such optimism (Table 3).

Continuous comparison of poverty figures for India is not possible since there was a change in the methodology for collection of data on consumption in 1999-2000, but it is clear that the rate of rural poverty reduction was higher in the 1980s than the 1990s. In terms of rural poverty although "official" estimates of poverty reduction between 19931994 and 1999-2000 are high (HC in rural areas fell from $37.27 \%$ to $27.09 \%$, and the number of poor from 244 million to 193.2 million over the period 1993-1999), the balance of evidence with careful adjustments of the 1999-2000 NSS data point to markedly lower reductions. ${ }^{5}$ Sen and Himanshu (2004) in a comprehensive and persuasive contribution cast doubts over earlier estimates of poverty reduction. As it turns out, the headcount ratio declined but at most by 3 percentage points, and the absolute number of the poor did not decline over 1993-1999. Preliminary estimates by Himanshu (2007) indicate that the rural HC declined to $28.7 \%$ in 2004-2005 (this is comparable to the 1993-1994 figure). Hence, over an 11-year period rural HC has declined by about 9 percentage points. Most of that decline (6 points) occurred in the 5-year period after 1999-2000. In contrast, the rural HC declined by almost 5 points in the 4-year period from 1983 to 1987. In the urban sector, the HC fell only by 6.7 percentage points from $32.6 \%$ in $1993-1994$ to 25.9 in $2004-2005$, partly because of increased migration from rural to urban areas.

In the early 1990s when poverty increased in response to the reforms, the percentage increase was greater for the rural PG and rural SPG than for rural HC (Jha, 2004). In fact, whenever there are sharpest adverse poverty shocks (defined as a $10 \%$ or higher increase in SPG), the worsening of rural PG and rural SPG is greater than of rural HC. ${ }^{6}$ Hence, the poorest of the poor suffer inordinately more during a period of severe adverse shocks and the poorest did not benefit as much as the other poor in a period of rapid growth.

There are at least six reasons for the slow rate of decline of poverty since the reforms. The first reason is statistical. As Ravallion (2003a) notes, the ratio of household survey (NSS) mean consumption to mean consumption from the national accounts in India is among the lowest in the world (60\% as compared to $95 \%$ on average). This has led informed observers to believe that poverty is overestimated in Indian data, compared especially to China, which has a much higher ratio of mean consumption computed from survey data to mean consumption from national accounts data. ${ }^{7}$ Over time, consumption may be increasingly underestimated, but there is no firm evidence to indicate its magnitude.

Second, although economic growth has been rapid, there have been only weak linkages between liberalization and agricultural growth on the one hand, and between the latter and poverty reduction on the other (Gaiha \& Kulkarni, 1998). Thus, although the growth rate of agricultural (crop) output was slightly higher during the 1990 s (3.08\% annually as 


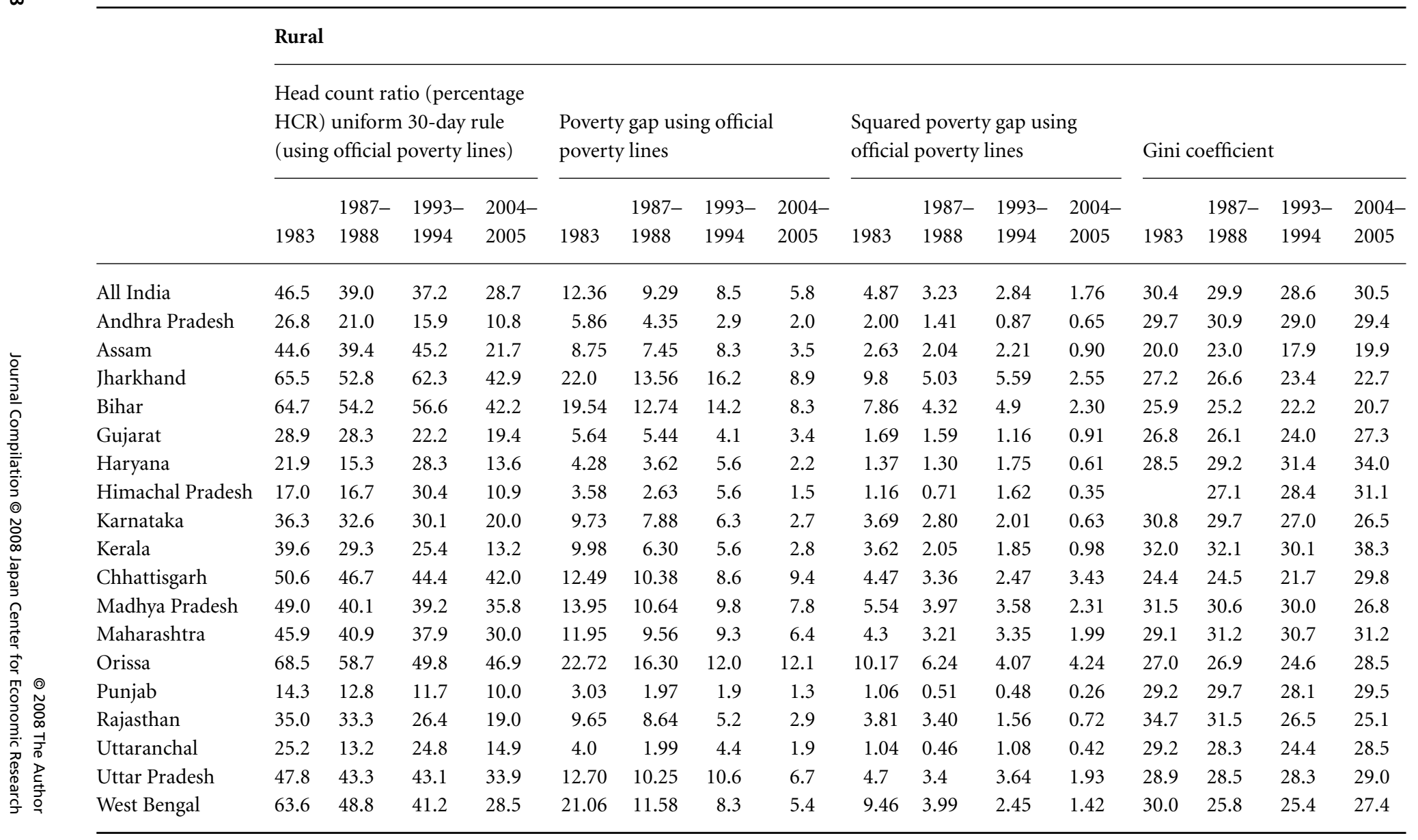


Table 3 Continued

Urban

Head count ratio (percentage HCR) uniform 30 day rule (using official poverty lines)

Poverty gap using official poverty lines
Squared poverty gap using official poverty lines

Gini coefficient

\begin{tabular}{|c|c|c|c|c|c|c|c|c|c|c|c|c|c|c|c|c|}
\hline & 1983 & $\begin{array}{l}1987- \\
1988\end{array}$ & $\begin{array}{l}1993- \\
1994\end{array}$ & $\begin{array}{l}2004- \\
2005\end{array}$ & 1983 & $\begin{array}{l}1987- \\
1988\end{array}$ & $\begin{array}{l}1993- \\
1994\end{array}$ & $\begin{array}{l}2004- \\
2005\end{array}$ & 1983 & $\begin{array}{l}1987- \\
1988\end{array}$ & $\begin{array}{l}1993- \\
1994\end{array}$ & $\begin{array}{l}2004- \\
2005\end{array}$ & 1983 & $\begin{array}{l}1987- \\
1988\end{array}$ & $\begin{array}{l}1993- \\
1994\end{array}$ & $\begin{array}{l}2004- \\
2005\end{array}$ \\
\hline All India & 43.6 & 38.7 & 32.6 & 25.9 & 11.4 & 10.2 & 8.0 & 6.2 & 4.4 & 3.8 & 2.9 & 2.0 & 33.9 & 35.0 & 34.4 & 37.6 \\
\hline Andhra Pradesh & 41.2 & 41.1 & 38.8 & 27.1 & 10.9 & 10.6 & 9.3 & 6.1 & 4.1 & 3.9 & 3.2 & 1.9 & 33.2 & 36.1 & 32.3 & 37.6 \\
\hline Assam & 25.9 & 11.3 & 7.9 & 3.7 & 5.6 & 1.5 & 0.9 & 0.5 & 1.7 & 0.3 & 0.2 & 0.1 & 26.1 & 31.0 & 29.0 & 32.1 \\
\hline Jharkhand & 40.5 & 34.6 & 26.5 & 20.7 & 10.9 & 7.8 & 5.2 & 4.7 & 4.2 & 2.6 & 1.6 & 1.5 & 30.9 & 32.1 & 32.5 & 35.5 \\
\hline Bihar & 61.6 & 63.8 & 40.7 & 38.1 & 18.5 & 16.6 & 9.7 & 9.3 & 7.1 & 5.9 & 3.4 & 3.0 & 28.5 & 26.6 & 28.2 & 33.3 \\
\hline Gujarat & 41.9 & 38.5 & 28.3 & 14.2 & 9.7 & 8.2 & 6.2 & 2.5 & 3.6 & 2.6 & 2.0 & 0.7 & 28.5 & 27.8 & 29.1 & 31.0 \\
\hline Haryana & 26.4 & 18.4 & 16.5 & 15.6 & 5.8 & 3.6 & 3.0 & 3.2 & 1.9 & 1.1 & 0.9 & 1.0 & 34.8 & 28.7 & 28.4 & 36.5 \\
\hline Himachal Pradesh & 11.0 & 7.2 & 9.3 & 5.0 & 2.8 & 0.7 & 1.2 & 1.0 & 1.1 & 0.1 & 0.3 & 0.3 & 35.8 & 29.2 & 46.2 & 32.6 \\
\hline Karnataka & 43.6 & 49.2 & 39.9 & 33.3 & 13.3 & 14.1 & 11.4 & 8.9 & 5.5 & 5.7 & 4.4 & 3.1 & 34.2 & 34.0 & 31.9 & 36.8 \\
\hline Kerala & 48.0 & 38.7 & 24.3 & 20.6 & 14.7 & 10.0 & 5.5 & 4.7 & 6.2 & 3.9 & 1.9 & 1.6 & 38.9 & 36.9 & 34.3 & 41.0 \\
\hline Chhattisgarh & 50.7 & 36.0 & 44.2 & 40.7 & 14.5 & 9.8 & 11.5 & 12.9 & 5.6 & 3.6 & 4.1 & 5.4 & 32.2 & 32.1 & 30.6 & 44.0 \\
\hline Madhya Pradesh & 56.1 & 50.0 & 49.0 & 42.3 & 16.1 & 14.5 & 13.9 & 12.4 & 6.2 & 5.6 & 5.3 & 4.8 & 29.8 & 33.3 & 33.6 & 39.7 \\
\hline Maharashtra & 41.1 & 40.5 & 35.0 & 32.8 & 12.1 & 12.4 & 10.2 & 9.2 & 4.9 & 5.2 & 4.2 & 3.5 & 34.6 & 34.8 & 35.7 & 37.8 \\
\hline Orissa & 54.0 & 42.6 & 40.6 & 43.7 & 16.7 & 11.1 & 11.4 & 14.1 & 7.1 & 4.2 & 4.3 & 5.8 & 29.0 & 31.0 & 30.7 & 35.4 \\
\hline Punjab & 22.9 & 13.7 & 10.9 & 5.0 & 5.9 & 2.3 & 1.7 & 0.6 & 2.3 & 0.6 & 0.4 & 0.1 & 33.9 & 28.8 & 28.1 & 40.3 \\
\hline Rajasthan & 41.2 & 37.9 & 31.0 & 28.5 & 11.5 & 9.6 & 7.0 & 6.2 & 4.7 & 3.4 & 2.2 & 1.9 & 33.9 & 34.6 & 29.3 & 37.2 \\
\hline Uttarakhand & 22.4 & 20.4 & 12.7 & 17.0 & 5.9 & 4.2 & 3.2 & 3.0 & 2.0 & 1.2 & 0.9 & 0.7 & 30.5 & 35.1 & 27.5 & 32.9 \\
\hline Uttar Pradesh & 52.7 & 46.4 & 36.1 & 30.7 & 15.1 & 12.7 & 9.3 & 7.2 & 5.9 & 4.7 & 3.4 & 2.3 & 31.5 & 33.5 & 32.6 & 36.9 \\
\hline West Bengal & 33.5 & 33.7 & 22.9 & 15.4 & 8.5 & 7.4 & 4.5 & 2.6 & 3.2 & 2.4 & 1.4 & 0.6 & 33.5 & 34.6 & 33.9 & 38.3 \\
\hline
\end{tabular}

Source: Himanshu (2007).

: Notes: Results for 1983, 1987-1988, and 1993-1994 are based on household level data and those for 2004-2005 on group data. NSS dates chosen refer to thick samples which yield more reliable estimates. 1999-2000 is omitted because of problems of comparability. Samples in intermediate years are small and are hence omitted from the analysis. 
against $2.94 \%$ during the 1980s), it slowed down to 1.6\% during 1997-1998 and 2000-2001 (Nayyar, 2003). Furthermore, whether agricultural growth translates into poverty reduction depends greatly on the distribution of the principal asset in agriculture: land. An implication of the existing highly unequal distribution of land is that the growth of real agricultural wages tends to be sluggish. Independently of agricultural growth, abrupt increases in price of food result in higher poverty. Furthermore, between 1993 and 1999, the employment elasticity of agricultural growth was barely 0.01 as compared to 0.70 during 1983-1993; there was near stagnation of real wages in agriculture with growth of these wages falling from $3.99 \%$ per annum during $1978-1979$ to $1989-1990$ to $2.34 \%$ annually during 1990-1991 to 1999-2000. Furthermore, the prices of food grains have, on occasion and particularly recently, accelerated at faster rates than the wholesale price index, leading to slow growth of the purchasing power of the section of society with the highest share of food in their expenditures (i.e. the poor).

Third, unlike many rapidly growing countries in East and South-East Asia where there has been rapid reduction of poverty, India did not experience a sharp increase in the demand for unskilled and semiskilled labor through expansion of labor-intensive manufacturing. Until the 1991 reforms, India's strategy for manufacturing sector expansion concentrated on capital-intensive industries in the public sector with only a limited role for private enterprise. Furthermore, there was significant anti-export bias, reflected partly in an overvalued exchange rate, and rigid product and labor markets with significant segments of industry reserved for small-scale investment and the firing of workers almost impossible. Since the reforms, although the overvaluation of the exchange rate has diminished considerably and industrial policy liberalized, significant, although reduced, segments of industry still remain reserved for the small-scale sector and little has been done to remove rigidities in labor markets. In addition, several East and South-East Asian countries have established a substantial head start over India in the area of low value-added manufacturing. Consequently, the current high rates of expansion of growth of the Indian economy are largely the result of expansion of the services sector and high valued-added manufacturing, with limited needs of semiskilled and unskilled labor.

Fourth, there has been an increase in personal inequality. Table 3 indicates that there has been a mild increase in the rural Gini coefficient and a much sharper increase in the urban Gini coefficient. The rise in inequality has been the result of three factors: (i) a shift in earnings from labor to capital income; (ii) the rapid growth of the services sector - particularly the FIIRE sector - with a consequent explosion in demand for skilled workers; and (iii) a drop in the rate of labor absorption during the reform period (Jha, 2004).

Fifth, India's expenditure on education has been inadequate and, thus, the incomeearning capacity of the labor force has been insufficiently augmented. Tilak (2006) reports that as late as 2004-2005 the government spent only 3.54\% of GNP on education, down from a high of $4.40 \%$ in $2000-2001$. Furthermore, if present trends continue, education expenditure as a percentage of GDP will be bound below 3.7\% until 2014-2015. This is to be contrasted with the recommendations of an important government commission (the Kothari Commission) set up in 1966 which had advocated that India spend at least $6 \%$ of GDP on education. Tilak (2007) estimates that, given the large rise in the proportion of 
youth in the Indian population, fulfilling even this recommendation of the Kothari Commission is likely to be inadequate to meet the educational requirements of the Indian population unless substantial private sector investment is forthcoming. In contrast to popular perception, budgetary allocations toward education are not unduly biased towards higher education. Tilak (2004) estimates that in 2000-2001, elementary education accounted for $48.9 \%$ of government expenditure on education up from 45.2 in 1992-1993 but down from 49.7 in 1997-1998. The share of higher education was 14.6\% in 2000-2001 up marginally from 13.0 in 1992-1993 and 11.8 in 1997-1998. Hence, it is not the allocation of education expenditures across elementary, secondary, technical, and higher education categories that is a problem - indeed past expenditure on higher education has enabled India to produce the technical personnel behind the current surge in economic growth - but the inadequate magnitude of the education budget.

Sixth, and finally, India's tax and transfer mechanism has not been sufficiently redistributive. The Ministry of Finance of the Government of India (2004) document the sharp growth in current subsidies, unrelated to capital formation, much of which is by the more welloff sections of society (e.g. the fertilizer, electricity, and water subsidies are available to rich farmers). Gemmell and Morrissey (2003) show that the tax structure in India is insufficiently progressive essentially because of its excessive reliance on commodity as opposed to direct taxation and the positive effective marginal rate, despite the existence of subsidies, on many commodities that are disproportionately represented in the consumption baskets of the poor.

\subsection{Regional concentration of poverty in India}

The aggregate economic growth narrative presented above masks substantial spatial variations. I computed standard deviations and means of real net state domestic product at factor cost for the following states and union territories: Andhra Pradesh, Assam, Bihar, Jharkhand, Goa, Gujarat, Haryana, Himachal Pradesh, Jammu and Kashmir, Karnataka, Kerala, Madhya Pradesh, Manipur, Meghalaya, Punjab, Rajasthan, Sikkim, Tamil Nadu, Uttar Pradesh, Uttarakhand, West Bengal, Delhi, and Pondicherry between 1993-1994 and 2004-2005. Although mean SDP per capita has risen, standard deviation has been rising even faster, and nearly doubled over this period, with the result that the coefficient of variation went up from 0.45 in 1993-1994 to 0.56 in 2004-2005, an increase of $24.4 \%$ in 12 years. ${ }^{9}$ Real state domestic products per capita are increasingly diverging (Figure 2).

The regional dispersion of poverty in India has also increased. The coefficients of variation of $\mathrm{HC}$ across the states depicted in Table 3 have risen over the reform period (19931994 to 2004-2005) for both the rural and urban sectors (from 0.39 to 0.50 for the rural sector and from 0.45 to 0.54 for the urban sector).

I conducted a modern test of rank convergence - Kendall's index of rank concordance (Boyle \& McCarthy, 1997) - to track the mobility of the states in respect of real mean consumption, the Gini coefficient, and the HC. The principal conclusions are as follows. ${ }^{10} \mathrm{By}$ and large, there has been remarkable stability in ranks across these states in regards to these critical welfare-determining variables and rank convergence does not obtain.

States may not converge in ranks, but may do so in levels. To check this, the levels test of Evans and Karras (1996), an improvement upon the standard ( $\beta$-type) tests of convergence, 


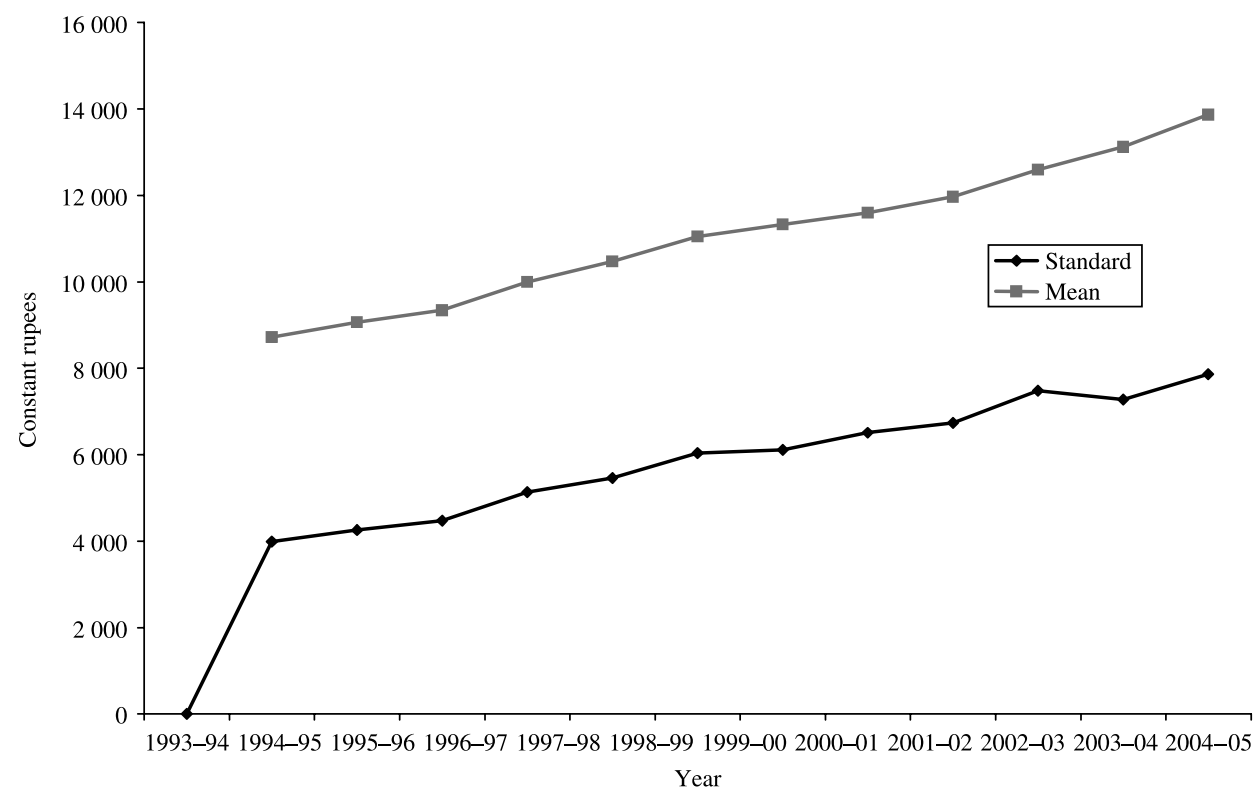

Figure 2 Standard deviation and mean of real net state domestic product per capita.

Source: Reserve Bank of India, Handbook of Statistics on the Indian Economy.

was carried out. The results indicate that for each of these variables, the value for any particular state is converging to its own mean, rather than to a grand mean for all the states. Thus, the HC for rural Bihar is converging to an average value peculiar to Bihar; the HC for rural Punjab is converging to an average peculiar to rural Punjab, and so on. With absolute convergence the $\mathrm{HC}$ for the rural sectors of all states would be converging to one grand mean.

\section{Incidence of Hunger in India and Some Implications}

Hunger is a very subjective term with no single, clear, universally accepted definition or modus operandi of measurement. In a recent document, the International Food Policy Research Institute (Ahmed et al., 2007a,b) defines hunger according to the number of calories consumed per day:

1 Subjacent hungry: those who consume between 1800 and 2200 calories per day

2 Medial hungry: those who consume between 1600 and 1800 calories per day

3 Ultra hungry: those who consume less than 1600 calories per day

2200 calories is the average energy requirement that, as recommended by international experts, is needed for adults undertaking light activity.

However, country-level definitions of hunger vary greatly. For India, Gopalan et al. (1971) indicate that the minimum calorific requirement for a male doing heavy work is 


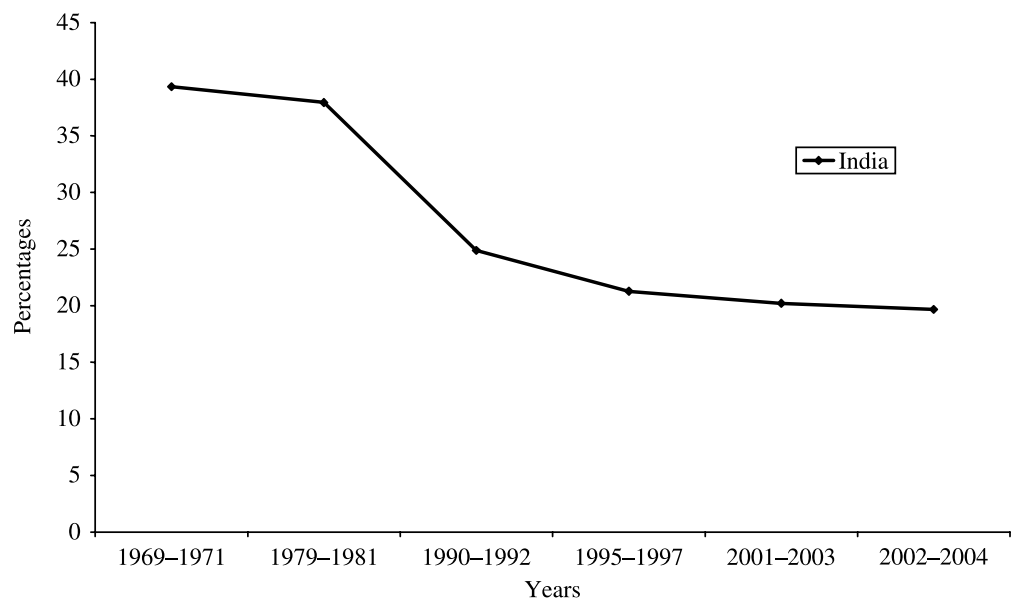

Figure 3 Percentage of population undernourished - India.

Source: Food and Agricultural Organization website (http://www.fao.org/corp/statistics.html?L=0).

3900 calories per day. The Food and Agriculture Organization (FAO) requirement of 2200 calories per person per day is highly aggregated and unable to account for the nutritional needs of differential groups, such as women and children and ignores other nutrients, particularly micronutrients. ${ }^{11}$

What is of particular concern is the fact that there was no significant reduction in hunger in recent years in India. Whereas hunger has come down sharply since the 1970s, there has been a slowdown in more recent times and the incidence of hunger in India has reached an asymptote (Figure 3). In the broader Asia-Pacific context, Ahmed et al. (2007a) compute the Global Hunger Index (Table 4) as an equally weighted average of lack of economic access to food, shortfalls in nutritional status of children, and child mortality, which shows that India's performance has been lackluster, although their latest figure (for 2003) may not be reliable since under 5-mortality rate (a constituent of the Global Hunger Index) fell from 123 in 1990 to 74 in 2005 but rose to 76 in 2006 (Asian Development Bank, 2008). With this sluggish rate of decline of hunger, India is unlikely to reach the hunger MDG by 2015.

Poverty is commonly seen as a root cause for hunger and malnutrition. Poor people not only struggle to acquire adequate quantities of food, but also face food insecurity because their diet often lacks essential micronutrients. However, hunger too is an important cause of poverty, although this causal linkage is less recognized. Undernourished people are less productive, while child malnutrition has severe and permanent consequences for physical and intellectual development; both these severely impair future earning capacity. The effects of poverty and malnutrition can often last over several generations.

The correlation between poverty and hunger is empirically not as high as would be expected theoretically. An important reason is that while income growth is a key requirement for hunger alleviation, it is by no means the only or most important one. Other important (and interlinked) requirements are access to health services, clean water, 
Table 4 Global Hunger Index (GHI) ranking of countries in the Asia-Pacific

\begin{tabular}{|c|c|c|c|c|c|c|c|}
\hline \multirow{2}{*}{$\begin{array}{l}\text { GHI } \\
\text { rank }\end{array}$} & \multirow[b]{2}{*}{ Countries } & \multicolumn{3}{|c|}{ Global Hunger Index } & \multirow{2}{*}{$\begin{array}{l}\text { Percentage } \\
\text { change between } \\
1992 \text { and } 1997\end{array}$} & \multirow{2}{*}{$\begin{array}{l}\text { Percentage } \\
\text { change between } \\
1997 \text { and } 2003\end{array}$} & \multirow{2}{*}{$\begin{array}{l}\text { Percentage } \\
\text { change between } \\
1992 \text { and } 2003\end{array}$} \\
\hline & & 1992 & 1997 & 2003 & & & \\
\hline 14 & Fiji & 7.14 & 5.97 & 3.07 & -16.39 & -48.58 & -57.00 \\
\hline 29 & Saudi Arabia & 6.87 & 7.40 & 5.44 & 7.71 & -26.49 & -20.82 \\
\hline 31 & Iran & 9.00 & 5.80 & 5.80 & -35.56 & 0.00 & -35.56 \\
\hline 40 & Malaysia & 10.17 & 7.73 & 7.23 & -23.99 & -6.47 & -28.91 \\
\hline 45 & Kazakhstan & & 4.96 & 8.17 & & 64.72 & \\
\hline 47 & China & 12.57 & 8.57 & 8.23 & -31.82 & -3.97 & -34.53 \\
\hline 48 & Kyrgyzstan & & 10.34 & 8.36 & & -19.15 & \\
\hline 52 & Azerbaijan & & 14.89 & 10.27 & & -31.03 & \\
\hline 53 & Turkmenistan & & 11.40 & 10.40 & $!$ & -8.77 & \\
\hline 58 & Thailand & 17.83 & 13.80 & 12.36 & -22.60 & -10.43 & -30.68 \\
\hline 59 & Indonesia & 18.53 & 15.60 & 12.47 & -15.81 & -20.06 & -32.70 \\
\hline 63 & Uzbekistan & & 11.74 & 13.60 & & 15.84 & \\
\hline 67 & Mongolia & 18.10 & 24.68 & 15.83 & 36.35 & -35.86 & -12.54 \\
\hline 68 & Myanmar & 19.33 & 15.53 & 16.17 & -19.66 & 4.12 & -16.35 \\
\hline 69 & Sri Lanka & 22.40 & 21.87 & 16.63 & -2.37 & -23.96 & -25.76 \\
\hline 72 & Philippines & 21.80 & 19.63 & 17.55 & -9.95 & -10.60 & -19.50 \\
\hline 75 & Vietnam & 25.93 & 22.37 & 18.37 & -13.73 & -17.88 & -29.16 \\
\hline 83 & North Korea & 15.51 & 20.91 & 20.33 & 34.82 & -2.77 & 31.08 \\
\hline 88 & Pakistan & 25.97 & 23.60 & 21.77 & -9.13 & -7.75 & -16.17 \\
\hline 89 & Timor-Leste & & & 22.29 & & & \\
\hline 91 & Laos & 25.83 & 26.73 & 23.83 & 3.48 & -10.85 & -7.74 \\
\hline 92 & Nepal & 27.77 & 27.77 & 24.50 & 0.00 & -11.78 & -11.78 \\
\hline 96 & India & 32.80 & 25.73 & 25.73 & -21.55 & 0.00 & -21.55 \\
\hline 102 & Bangladesh & 36.50 & 35.73 & 28.27 & -2.11 & -20.88 & -22.55 \\
\hline 108 & Tajikistan & & 19.86 & 30.25 & & 52.32 & \\
\hline 109 & Cambodia & 33.03 & 36.03 & 30.73 & 9.08 & -14.71 & -6.96 \\
\hline
\end{tabular}

Source: Ahmed et al. (2007a) and author's computation.

sanitation, and education. The relationship between prices for food and nonfood items in an aggregate price index influences how poverty translates into hunger and malnutrition; for example, if nonfood items become cheaper compared to food (as is the general case, with prices falling due to better technologies), then people may not be classified as poor, even though their nutritional requirements are not met.

The impact of hunger and poverty on adult men is different from that on vulnerable sections of society, such as women, children, landless, and backward classes. Women and female children are more likely to be poorer, especially in male-headed households (Ahmed et al., 2007b). Furthermore, children in female-headed households are more likely to have better nutrition, since women are more likely to place greater priority on 
food and health than do men. However, in India most datasets are at the household level and not at individual level, making inferences about intrahousehold discrimination difficult (see Sinha, 2007). Moreover, people of indigenous, tribal, or otherwise vulnerable backgrounds are more likely to be poor and suffering from undernutrition because of their overall lower levels of education, marginalized status, and relatively restricted access to economic opportunities.

The poorest regions within the country are frequently also the remotest, with the highest travel time to the main economic centers. Moreover, road and other transport infrastructure are sparse, if not nonexistent. Inability to access markets means that people generally have to grow their own food for consumption. Food insecurity and nutrient deficiency is also high (especially among children), which affects productivity. Therefore, the central government has a role in not only helping develop competitive market mechanisms, but also in developing proper transport infrastructure (that links remote areas to main market centers) and market information. The government also has a role in providing mechanisms by which people from these areas are able to protect themselves from marketing, pricing, weather, and production risks.

Undernutrition reduces economic growth, both actual and potential, as Arcand (2001) argues. He finds a statistically significant and quantitatively important impact of nutrition on growth, with the result being robust to the use of three different multicountry (including India) datasets and of a multitude of different econometric procedures.

\section{Conclusions and Policy Implications}

My conclusions are grouped in two categories: one directed toward poverty, the discussion on which will be brief, and the other addressing hunger, with a more substantial discussion.

There is a large literature on strategies for poverty reduction in India. I provide only a brief overview in line with the six reasons for slow reduction in poverty in the post-reform period enunciated earlier. To stimulate rural development and lower rural poverty on an emergent basis, there needs to be redirection of public investment toward the rural sector, properly targeted both in terms of regions - those with high poverty and rainfed areas ${ }^{12}-$ as well as people - the landless and small farmers. As Gutierrez et al. (2007) argue, rural, nonagricultural development and employment-intensive manufacturing sector development are crucial for rural poverty reduction. Infrastructural bottlenecks are a persistent hindrance to this. Private sector investment in infrastructure is definitely needed but the private sector would not be interested in the poorest areas without substantial inducement and public investment. This will be facilitated by pruning of subsidies, particularly those that lead to overexploitation of water resources and inappropriate fertilizer use. Reform of input price policy is necessary to ensure that such investment is not mis-targeted. Monetary policy should be more sensitive to movements in consumer price indices for agricultural laborers and industrial workers until a comprehensive consumer price index for the economy is developed. ${ }^{13}$ The central government must pursue policies that sustain high economic growth and reduce emerging inequalities. Concurrently, reform of 
social safety nets, including the public distribution system and subsides as well as employment guarantee schemes, needs to be put into effect. Resources devoted to education need to substantially augmented and there needs to be an expansion of labor-intensive manufactures, although options with regard to this may be limited given that many South-East and East Asian countries have already established a strong niche for these products in global markets.

Ensuring food security is a complex and multifaceted goal, the achievement of which would require coordinated inputs by a variety of stakeholders. I discuss some important elements in a strategy to tackle hunger in India.

A key question is will higher incomes, consequent upon higher economic growth, lead to better nutrition? Behrman and Deolalikar (1989) argue that the income elasticity of calorific consumption is very low (i.e. calorific consumption would not increase simply as a result of increased incomes). If these relative income elasticities reflect informed choices, then the hungry of the developing countries place far lesser priority in nutrition than that suggested by analysts and policy-makers. Furthermore, with well-informed choices the goal of increasing nutritional intake could be better achieved through policies directly targeting food consumption, rather than income.

The contrasting, and more traditional view, is represented by Subramanian and Deaton (1996), who show for the Indian state of Maharashtra that the income elasticity of calorific consumption is 0.3 to 0.5 . The differences in the two results arise from the data and econometric techniques used. The latter study uses a much larger sample and controls for unobserved heterogeneity and thus yields more accurate estimates. Jha et al. (2009) using an all-India sample find calorie elasticity values that are significant and between the values given by Behrman and Deolalikar (1989) and by Subramanian and Deaton (1996). Hence, income increases do lead to increases in calorie intake but not by much.

Policies to achieve increased food supplies include research on and provision of highyielding seed varieties for farmers. Farm credit should be made available on favorable terms to enable financing of and increased use of fertilizers and farm machinery. Policies and government intervention to promote increased irrigation would also augment output, especially since water supplies and irrigation patterns vary considerably over the country.

According to some reports, there are enough aggregate food supplies and production to meet the needs of the poor and hungry, but the real problem is with food distribution and access. Improving food distribution primarily requires policies that are not necessarily agricultural in nature, but rather are part of a wider infrastructure and logistics development program. Development of road and rail infrastructure would connect rural and remote areas with important economic and transportation hubs, thus allowing easy, economical transportation of food items to these areas. Distribution requires enabling the increased use of refrigeration/freezing facilities, so that minimum amounts of food get spoiled during transport and storage. This could be achieved through increased education about benefits of technology, and cheaper, more accessible credit. Governments at various levels must ensure development of competitive yet equitable market mechanisms that facilitate trade of food items.

Governments could ensure enhanced nutrient intake by widely disseminating nutritional information (including its importance) among the poor and hungry. Since women 
place greater priority on nutrition and health than men, the bulk of cash grants or income redistribution policies should be targeted at women. ${ }^{14}$ Additionally, conditional cash transfers could be used to ensure minimum dietary intakes (Aguero et al., 2007).

Krishnakumar (2005) has noted the impact of maternal health and nutrition on the health and nutrition of their offspring. One of the reasons for the high incidence of child malnutrition in India is that the mothers are undernourished, have poor health, relatively high fertility, and encounter unacceptable levels of risk during pregnancy and childbirth. Thus, improving maternal health and nutritional outcomes is essential to a program of reducing hunger. In this context Sinha (2007) finds for rural India that transfers made to women within the household have a greater positive impact on household (including child) nutrition than if these transfers were made to male members of the household. Thus, a proactive program of women's participation and empowerment is central to a policy aiming to reduce hunger.

The best and most well-intentioned policies will be ineffective, or even counterproductive, if they are not properly implemented. Local governments are ultimately responsible for ensuring that available food gets distributed evenly in various spatial locations and across backward/disadvantaged groups. In India, the right to food has been legislated and has had favorable impacts on food security for the poor. However, for the right to food to be effective, supporting mechanisms in the form of a vibrant civil society and an efficient and impartial judiciary are needed (Bhargava \& Balana, 2006).

Cline (2007) has argued that over the long run India faces very significant losses in agricultural productivity because of climate change. The central government must proactively study and anticipate the implications of climate change for agriculture and food availability. There is much that the international community can do to address this pressing issue. The increasing use of grain for biofuel production has been exerting upward pressures on prices of wheat and other important grains.

Problems such as poverty and hunger cannot be addressed in isolation, but in conjunction with policies regarding other interconnected problems, such as maternal and child health, child mortality, education, etc. Governments at various levels are primarily responsible for a comprehensive social policy framework.

\section{Notes}

1 For a comprehensive perspective on and review of Indian economic reforms, see Ahluwalia (2002). Datt and Ravallion (2002) and Jha (2004) provide reviews of the impact of economic reforms on poverty in India.

2 The share of the rural sector in India's population declined by just over 2 percentage points between the 1991 and 2001 censuses, and only by a little less than 17 percentage points in the 100 years between the 1901 and 2001 censuses.

3 There are other indicators of the decline of the rural/agricultural sector in the post-reforms period. Between 1992-1993 and 2003-2004, the growth rate of crop output decelerated to $1.18 \%$ per annum from $3.19 \%$ during $1980-1981$ to $1991-1992$, while food grain output increased only by $1.16 \%$ per annum during $1992-1993$ to $2003-2004$. This was below the rate of population growth thus leading to a drop in food grain availability (Bhalla, 2007). 
4 Figure 1 is drawn to both include and exclude the low growth years of 1990-1991 (economic crisis) and 2002-2003 (drought) to underscore the point that the basic trends in growth remain whether these two unusual years are included.

5 There was a change in the method of data collection during the 55th round of NSS conducted in 1999-2000 rendering it incomparable with earlier rounds.

6 A further example of this is the increase in poverty following the severe drought in 1987.

7 Ravallion (2003b) indicates two significant reasons for this difference. Survey data exclude imputed housing rents and the imputed services of households of financial intermediaries. National accounts figures include these. Furthermore, national account figures include the expenditures of India's entire nongovernmental, nonprofit sector. Both of these are likely to be an increasing share of total consumption. Rural sector data are also incompletely collected because of the presence of a large informal sector.

8 FIIRE refers to Finance, Insurance, Internet and Real Estate (Atkinson, 1999). These sectors have been experiencing the most buoyant growth in recent years in many countries, including India.

9 Although the trend in coefficient of variation is distinctly upward, there was a drop between 2002-2003 and 2003-2004, following which there was a resumption of the upward trend.

10 The analysis is carried out for the period 1953-1997. Results are not reported to conserve space but are available from the author. The dispersion of HDI indicators across Indian states broadly follows the dispersion of poverty (Deolalikar, 2008).

11 Svedberg (1999) provides a critique of FAO methodology.

12 Fan and Hazell (2000) classify districts into irrigated, and high and low potential rainfed areas and compute impacts (direct and indirect) of different types of infrastructure and technology on production and poverty (e.g. roads contribute directly to production and on poverty through the effect of production on wages). The main findings are: for every investment, the highest marginal impact on production and poverty alleviation occurs in one of the two types of rainfed areas, while irrigated areas rank second or last. Many types of investments in low potential rainfed areas yield some of the highest production returns, and all types of investment except markets and education have some of the most favorable impacts on poverty. Thus, the potential of larger investments in such areas, for poverty alleviation as well as production returns is high.

13 Jha et al. (2006) show with robust regression for 20 states and 56 NSS regions for 2004 that whereas increases in per capita expenditure and decreases in per unit price of food grains lower poverty (both significantly) the impact of the latter is greater.

14 An important reason for child malnutrition is the undernourishment of the mothers of these children during pregnancy (Rao, 2004). Hence, improving child and maternal nutritional outcomes are inextricably linked together.

\section{References}

Aguero J., Carter M., Woolard I. (2007). The impact of unconditional cash transfers on nutrition: The South African Child Support Grant. Working Paper no. 39, International Poverty Centre, UNDP, Brasilia.

Ahluwalia M. (2002). Economic reforms in India since 1991: Has gradualism worked? Journal of Economic Perspectives 16 (3), 67-88.

Ahmed A.U., Hill R.V., Smith L.C., Wiesmann D.M., Frankenberger T. (2007a). The world's most deprived: Characteristics and causes of extreme poverty and hunger. Discussion Paper no. 43 prepared for the Forum “A 2020 Vision for Food, Agriculture, and the Environment"; October 2007, International Food Policy Research Institute, Washington, DC. 
Ahmed A.U., Hill R.V., Smith L.C., Wiesmann D.M., Frankenberger T. (2007b). Asia's poorest and hungry: Trends and characteristic. Prepared for Policy Forum "Agricultural and Rural Development for Reducing Poverty and Hunger in Asia: In Pursuit of Inclusive and Sustainable Growth"; August 9-10, 2007, Asian Development Bank and International Food Policy Research Institute, Manila.

Arcand J. (2001). Undernourishment and Economic Growth: The Efficiency Cost of Hunger. Food and Agriculture Organization Economic and Social Development Paper 147. Rome: FAO.

Asian Development Bank (2008). Basic Statistics 2008: Developing Member Countries. Manila: ADB.

Atkinson A.B. (1999). Is rising income inequality inevitable? A critique of the transatlantic consensus. World Institute for Development Economics Research Annual Lectures 3, United Nations University-WIDER, Helsinki.

Behrman J.R., Deolalikar A. (1989). Is variety the spice of life? Implications for calorie intake. Review of Economics and Statistics 71 (4), 666-672.

Bhalla G.S. (2007). Indian Agriculture Since Independence. New Delhi: National Book Trust.

Bhargava P., Balana M. (2006). Realizing the Right to Food in South Asia. Research Paper 2006/122, Helsinki: World Institute for Development Economics Research.

Boyle G., McCarthy T. (1997). A simple measure of $\beta$ convergence. Oxford Bulletin of Economics and Statistics 59 (2), 257-264.

Cline W. (2007). Global Warming and Agriculture. Washington DC: Center for Global Development, Peterson Institute for International Economics.

Datt G., Ravallion M. (2002). Is India's economic growth leaving the poor behind? Journal of Economic Perspectives 16 (3), 89-108.

Deolalikar A. (2008). Human development in India: Past trends and future challenges. In: Jha R. (ed.), The Indian Economy Sixty Years After Independence. Basingstoke: Palgrave Macmillan, 115178.

Evans P., Karras G. (1996). Convergence revisited. Journal of Monetary Economics 37 (2), 249-265.

Fan S., Hazell P. (2000). Should developing countries invest more in less-favoured areas? An empirical analysis of rural India. Economic and Political Weekly 35 (17), 1455-1464.

Foster J., Greer J., Thorbecke E. (1984). A class of decomposable poverty measures. Econometrica 52 (3), 761-765.

Gaiha R., Kulkarni V. (1998). Is growth central to poverty alleviation in India? Journal of International Affairs 52 (1), 145-180.

Gemmell N., Morrissey O. (2003). Tax Structures and the Incidence on the Poor in Developing Countries. CREDIT Research Paper 03/18, Nottingham: University of Nottingham.

Gopalan C., Sastri B., Balasubramanian S. (1971). Nutritive Value of Indian Foods. Hyderabad: National Institute of Nutrition, Indian Council of Medical Research.

Ministry of Finance, Government of India (2004). Central Government Subsidies in India. [Cited May 2008]. Available from http://finmin.nic.in/downloads/reports/cgsi-2004.pdf.

Gutierrez C., Orecchia C., Paci P., Serneels P. (2007) Does employment generation really matter for poverty reduction. Policy Research Working Paper no. 4432, Washington DC: World Bank.

Himanshu (2007). Recent trends in poverty and inequality: Some preliminary results. Economic and Political Weekly 42 (6), 497-508.

Jha R. (2004) Reducing poverty and inequality in India: Has liberalization helped. In: Cornia A. (ed.), Inequality, Growth and Poverty in an Era of Liberalization and Globalization. New York: Oxford University Press, 297-326.

Jha R., Gaiha R., Sharma A. (2006). Mean consumption, poverty and inequality in rural India in the 
Sixtieth Round of the National Sample Survey. Australia South Asia Research Center Working Paper no. 2006/11, Canberra: Australian National University.

Jha R., Gaiha R., Sharma A. (2009). Modelling variety in consumption expenditure on food in India. International Review of Applied Economics 23 (4), forthcoming.

Kelkar V. (2004). India on the Growth Turnpike. Canberra: K.R. Narayanan Oration, Australia South Asia Research Centre, Australian National University.

Krishnakumar A. (2005). An invisible emergency. Frontline 22 (9), April 23-May 06.

Nayyar R. (2003). India Country Study. New Delhi: Planning Commission, Government of India.

Rao G.M.S. (2004). Food for thought. The Hindu, September 12. [Cited 8 May, 2008]. Available from http://www. hinduonnet.com/thehindu/mag/2004/09/12/stories/2004091200090400.htm

Ravallion M. (2003a). Measuring aggregate welfare in developing countries: How well do national accounts and surveys agree? Review of Economics and Statistics 85 (3), 645-642.

Ravallion M. (2003b). Fanciful numbers and fictitious intrigues. Economic and Political Weekly 38 (44), 4653-4654.

Reserve Bank of India. Handbook of Statistics on the Indian Economy. Mumbai, India.

Sen A., Himanshu (2004). Poverty and inequality in India - 1. Economic and Political Weekly 39 (38), $4247-4263$.

Sinha K. (2007). Essays in nutrition and labor supply: An empirical investigation for rural India (PhD dissertation). Australian National University, Canberra.

Subramanian S., Deaton A. (1996). The demand for food and calories. Journal of Political Economy 104 (11), 133-162.

Svedberg P. (1999). 841 million undernourished? World Development 27 (12), 2081-2088.

Tilak J. (2004). Public subsidies in education in India. Economic and Political Weekly 39, 343-359.

Tilak J. (2006). On allocating 6\% of GDP to education. Economic and Political Weekly 41, 613-618.

Tilak J. (2007). The Kothari Commission and financing of education. Economic and Political Weekly 42, 874-882.

United Nations Development Program (UNDP). Human Development Report: 2007-2008. 